\title{
13-week Pulmonary Sonoangiogram by 3D HDlive Flow
}

\author{
Ritsuko K Pooh
}

\section{ABSTRACT}

Recent development of three-dimensional (3D)/four-dimensional (4D) sonography has revealed structural and functional early human development in utero and 3D/4D sonography moved prenatal diagnosis of fetal anomalies from the second to the first trimester of pregnancy. HDlive flow is a recent application of 3D ultrasound technology generating a 3D-view of the blood flow and providing a realistic rendering of fine vascular structure. Combination of HDlive silhouette and flow can be described as a 'see-through fashion', because of its comprehensive orientation and persuasive localization of inner structure as well as of fetal angiostructure inside the morphological structure.

The picture of this month demonstrates normal intracorporeal angiostructure by 3D HDlive silhouette/flow imaging with bidirectional power Doppler at 13 weeks of gestation. The umbilical arteries, umbilical vein, ductus venosus, inferior vena cava, descending aorta as well as rich pulmonary vascularity are clearly demonstrated in a single 3D reconstructed image. This image indicates existence of rich pulmonary vascularity from even before lung maturation in the first trimester.

Prenatal prediction of neonatal prognosis in cases with still remains a challenge but previous trials have been done after 20 weeks of gestation. Nowadays, many of pulmonary lesions, such as congenital diaphragmatic hernia (CDH) and congenital cystic adenomatoid malformation (CCAM), have been diagnosed in the first or early second trimesters. Recent advanced imaging technology of HDlive flow showing pulmonary vasculature from the first trimester in this article may have a great potential to investigate fetal lung development and maturity from early gestation and lead to scheduling of prenatal fetal treatment and proper management.

Keywords: Fetus, HDlive flow, Prenatal diagnosis, Pulmonary, Sonoangiogram, Three-dimensional ultrasound.

How to cite this article: Pooh RK. 13-week Pulmonary Sonoangiogram by 3D HDlive Flow. Donald School J Ultrasound Obstet Gynecol 2015;9(4):355-356.

Source of support: Nil

Conflict of interest: None

\section{PULMONARY SONOANGIOGRAM AT 13 WEEKS}

Recent development of three-dimensional (3D)/fourdimensional (4D) sonography has revealed structural

\section{President}

CRIFM Clinical Research Institute of Fetal Medicine Pooh Maternity Clinic, Osaka, Japan

Corresponding Author: Ritsuko K Pooh, President, CRIFM Clinical Research Institute of Fetal Medicine Pooh Maternity Clinic, Matsushita Building 3F, 1-24, Uehommachi 7, Tennoji Osaka City, 543-0001, Japan, e-mail: pooh27ritsuko@fetalmedicine-pooh.com and functional early human development in utero ${ }^{1,2}$ and 3D/4D sonography moved prenatal diagnosis of fetal anomalies from the second to the first trimester of pregnancy. ${ }^{3}$ HDlive flow ${ }^{4-6}$ is a recent application of $3 \mathrm{D}$ ultrasound technology generating a 3D-view of the blood flow and providing a realistic rendering of fine vascular structure. Combination of HDlive silhouette and flow can be described as a 'see-through fashion', 5,6 because of its comprehensive orientation and persuasive localization of inner structure as well as of fetal angiostructure inside the morphological structure. ${ }^{5}$

The picture of this month (Fig. 1) demonstrates normal intracorporeal angiostructure by 3D HDlive silhouette/ flow imaging with bidirectional power Doppler at 13 weeks of gestation. The umbilical arteries, umbilical vein, ductus venosus, inferior vena cava, descending aorta as well as rich pulmonary vascularity are clearly demonstrated in a single 3D reconstructed image. This image indicates existence of rich pulmonary vascularity from even before lung maturation in the first trimester.

Mahieu-Caputo et $\mathrm{al}^{7}$ suggested the number of bifurcations of the pulmonary vessels in the lung contralateral to the diaphragmatic hernia evaluated by conventional 2D power Doppler imaging. Thereafter Dubiel et $\mathrm{al}^{8}$ performed the quantitative analysis of 3D power Doppler angiography signal after 24 weeks of gestation and showed an increase in fetal pulmonary 3D power Doppler angio-intensity until 33 weeks and

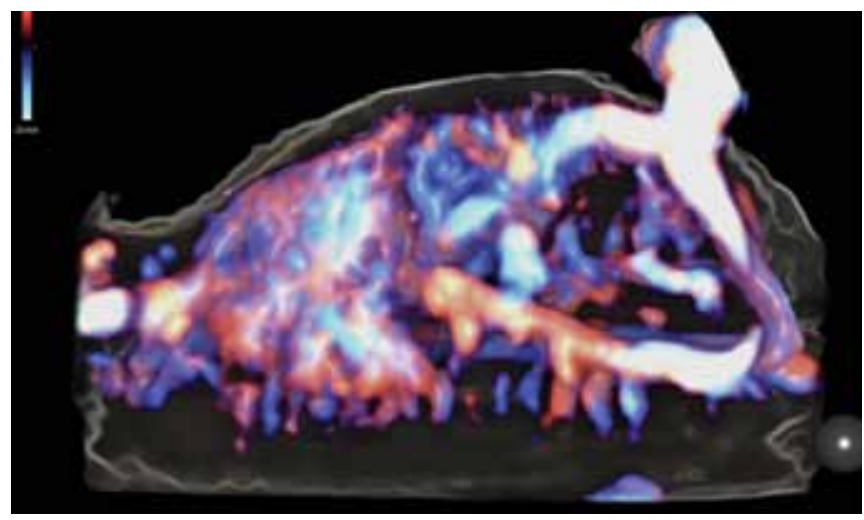

Fig. 1: Fetal pulmonary sonoangiogram at 13 weeks of gestation. Fetal intracorporeal angiostructure is demonstrated by $3 \mathrm{D}$ HDlive silhouette/flow imaging with bidirectional power Doppler at 13 weeks of gestation. The umbilical arteries, umbilical vein, ductus venosus, inferior vena cava, descending aorta as well as rich pulmonary vascularity are clearly demonstrated in a single $3 \mathrm{D}$ reconstructed image. This image indicates existence of rich pulmonary vascularity from even before lung maturation in the first trimester 
a decrease after 38 weeks. Ruano et $\mathrm{al}^{9}$ utilized the 3D power Doppler histogram after 20 weeks to determine the vascular indices and evaluate the pulmonary vasculature quantitatively in cases of congenital diaphragmatic hernia $(\mathrm{CDH})$ using a combined method of 3D imaging and 3D power Doppler assessing the volume and quantifying the power Doppler signal. Thus, prenatal prediction of neonatal prognosis in cases with pulmonary hypoplasia still remains a challenge and all of previous trials have been done after 20 weeks of gestation.

Nowadays, many of pulmonary lesions, such as $\mathrm{CDH}$ and congenital cystic adenomatoid malformation (CCAM), have been diagnosed in the first or early second trimesters. Recent advanced imaging technology of HDlive flow showing pulmonary vasculature from the first trimester in this article may have a great potential to investigate fetal lung development and maturity from early gestation and lead to scheduling of prenatal fetal treatment and proper management.

\section{REFERENCES}

1. Pooh RK, Shiota K, Kurjak A. Imaging of the human embryo with magnetic resonance imaging microscopy and highresolution transvaginal 3-dimensional sonography: human embryology in the 21st century. Am J Obstet Gynecol 2011;204(1):77.e1-16.
2. Pooh RK. Three-dimensional sonoembryology. Donald School J Ultrasound Obstet Gynecol 2011;5(1):7-15.

3. Pooh RK, Kurjak A. Editorial. 3D/4D sonography moved prenatal diagnosis of fetal anomalies from the second to the first trimester of pregnancy. J Maternal-Fetal Neonatal Medicine 2012;25(5):433-455.

4. Pooh RK. Brand new technology of HDlive silhouette and HDlive flow images. In Donald School Atlas of Advanced Ultrasound in Obstetrics and Gynecology by Pooh RK and Kurjak A. Jaypee Brothers Medical Publishers (P) Ltd., New Delhi; 2015. p. 1-39.

5. Pooh RK. 'See-through fashion' in prenatal diagnostic imaging. Donald School J Ultrasound Obstet Gynecol 2015;9(2):111.

6. Pooh RK. A new field of 'Fetal Sono-ophthalmology' by 3D HDlive silhouette and flow. Donald School J Ultrasound Obstet Gynecol 2015;9(3):221-222.

7. Mahieu-Caputo D, Aubry MC, El Sayed M, Joubin L, Thalabard JC, Dommergues M. Evaluation of fetal pulmonary vasculature by power Doppler imaging in congenital diaphragmatic hernia. J Ultrasound Med 2004;23:1011-1017.

8. Dubiel M, Breborowicz GH, Ropacka M, Pietryga M, Maulik $\mathrm{D}, \mathrm{Gudmundsson}$ S. Computer analysis of three-dimensional power angiography images of foetal cerebral, lung and placental circulation in normal and high-risk pregnancy. Ultrasound in Medicine and Biology 2005;31(3):321-327.

9. Ruano R, Aubry MC, Barthe B, Mitanchez D, Dumez Y, Benachi A. Quantitative analysis of fetal pulmonary vasculature by 3-dimensional power Doppler ultrasonography in isolated congenital diaphragmatic hernia. Am J Obstet Gynecol 2006 Dec;195(6):1720-1728. 